\title{
DE BRITSCH-INDIËRS IN SURINAME
}

door

\section{DE KLERK C.SS.R.}

In het voorwoord van het zeer verdienstelijke werk: „De Britsch-Indiërs in Suriname" door den Herrnhutter zendeling Rudolf Karsten noemt de oud-kantonrechter uit Paramaribo Mr F. G. Schalkwijk Suriname, ,dat Zuid-Amerikaansche stukje Nederlandsch gebied, waarvan de bekoring hem, die er eenmaal was, nimmer loslaat".

Ik geloof, dat degenen van mijn lezers, die in Suriname eenige jaren hebben gearbeid, of het voor een korteren tijd hebben bezocht, met dat woord van harte zullen instemmen. Inderdaad, gelijk de geboren Surinamer, die zich elders in de wereld heeft gevestigd, steeds met heimwee naar zijn geboortegrond heeft te kampen, zoo heeft ook ieder West-Indischman, die uit Suriname naar het Moederland is teruggekeerd, daarginds een stukje van zijn hart achtergelaten. Dat is mijn ervaring, niet alleen in eigen kring van oud-missionarissen uit Suriname, maar bij oudambtenaren van het gouvernement, militairen, employé's van handels- of scheepvaartondernemingen, die ik hier te lande mocht ontmoeten.

Het toevallig samentreffen van twee „oud-Kolonialen”, zal ik ze maar noemen, geeft daarom vaak aanleiding tot de warmste ontboezemingen. Zoo stapte ik onlangs te Roozendaal een volle treincoupé binnen. Met moeite trachtte ik mijn handvalies in het net te werken, toen ik opeens in het gedrang werd aangeklampt door iemand met de vraag: ,Eerwaarde, komt U uit Suriname? Ik zie daar op uw valies een label van de Suriname-lijn". Mijn bevestiging hierop bood den vrager een welkome gelegenheid om zijn hart eens te luchten door allerlei aardige herinneringen aan Suriname op te halen. Toch was het een man, die als scheepskapper van de „Stuyvesant” telkens met tusschenpoozen slechts enkele dagen in Paramaribo had doorgebracht.

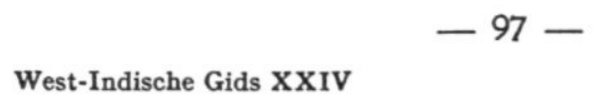


Het is mij daarom een groot genoegen, dat ik van de redactie van „De West-Indische Gids” de vereerende uitnoodiging mocht ontvangen, over ons West-Indisch gebiedsdeel, dat ook mij lief is, en welks lot elk Groot-Nederlander, vooral in deze bewogen dagen, ten zeerste ter harte gaat, een artikel te willen schrijven.

In verband met mijn arbeid in 't verleden heb ik als onderwerp voor mijn artikel gekozen: de Britsch-Indièrs in Suriname, een bevolkingsgroep, die, zooals de bekende sanscritist en archaeoloog Prof. Vogel van Leiden in het reeds genoemde voorwoord opmerkt, „,een bijzondere aanspraak maakt op onze belangstelling, niet alleen omdat de Br.-Indiërs een factor van economische beteekenis vormen in de Kolonie, maar ook omdat zij vertegenwoordigers zijn van een overoude en hoogst merkwaardige cultuur en sprekers van een taal, die, zij het ook in de verte, verwant is aan de onze".

Ik stel mij voor in mijn artikel vijf punten kort te behandelen:

I. de geschiedenis van de immigratie der Br.-Indiërs;

II. hun economische beteekenis voor Suriname;

III. hun verhouding tot de andere bevolkingsgroepen;

IV. hun verhouding tot het gouvernement;

V. hun verhouding tot het Christendom.

I. Geschiedenis van de immigratie $\left.{ }^{1}\right)$.

Onder de vele rassen, die in Suriname vertegenwoordigd zijn, geeft geen bevolkingsgroep daaraan zulk een schilderachtig cachet als die der Br.-Indiërs. Iedere nieuw aangekomene, die in Paramaribo aan wal stapt, wordt aanstonds getroffen, door de opvallende plaats, die zij in het straatbeeld van de stad innemen. Overal komt hij ze tegen, meestal in kleine groepjes, met hun scherpe, vaak fijngevormde, Arische trekken, de vrouwen met sluiers en in kleurige kleedij, overvloedig met sieraden getooid, de mannen in hun eenvoudige witte dhóti en chaddar, elkander groetend met den heilwensch, die ons Europeanen in 't begin vooral weldadig aandoet: Salām! salām! Vrede! vrede!

De vraag rijst dan vanzelf: Hoe komen die menschen in Suriname?

Het antwoord hierop kan men kort samenvatten: tengevolge van de vrijmaking der negerslaven.

In 1834 en 1848 was de slavernij achtereenvolgens in de Britsche en de Fransche bezittingen afgeschaft. Men begreep toen

1) De gegevens voor deze geschiedenis heb ik gedeeltelijk ontleend aan Karsten: ,,De Britsch-Indiërs in Suriname”, uitgegeven in 1930 bij M. Nijhoff te 's-Gravenhage. 
in Suriname, dat ook hier de emancipatie niet ver meer af zou zijn; en, gezien het feit, dat in de andere koloniën de vrijgelaten slaven niet meer vrijwillig op de plantages wilden werken, begon men in Suriname ook uit te zien naar nieuwe arbeidskrachten. Men probeerde het eerst in 1853-54 met Chineezen en Portugeezen van Madeira. Maar deze immigratieproeven mislukten. De Chineezen en Madeireezen voldeden wel als arbeiders, maar zoodra hun contract was afgeloopen, gingen zij zich als winkeliers in de kolonie vestigen. Het gevolg hiervan is geweest, dat de kleinhandel in Suriname voor een groot deel thans nog in hun handen is: bijna alle winkels, waar kruidenierswaren en comestibles verkocht worden, behooren aan Chineezen, terwijl de Madeireezen bij voorkeur manufacturenwinkels zijn gaan houden. Dit laatste bedrijf deelen de Madeireezen met de Syriērs, die uit den Libanon afkomstig zijn en overal in West-Indië worden aangetroffen.

Met ingang van 1 Juli 1863 werd eindelijk ook in Suriname door Koning Willem III de slavernij afgeschaft, een datum, die elk jaar nog door de zwarte Creoolsche bevolking feestelijk wordt herdacht. $45000^{1}$ ) slaven kregen op dat tijdstip de vrijheid, hetgeen natuurlijk een heele maatschappelijke ommekeer teweegbracht. Wel lieten die gevolgen zich niet aanstonds zoo sterk gevoelen, daar de vrijgelaten slaven de eerste 10 jaar nog onder toezicht van de regeering werden gesteld, opdat niet allen tegelijk de plantages zouden verlaten, maar meer geleidelijk in de burgermaatschappij zouden worden opgenomen.

Intusschen hield het vraagstuk van de aanwerving van nieuwe arbeidskrachten voor de plantages de regeering bij voortduring bezig. Na lange onderhandelingen werd ten slotte in 1872 tusschen Nederland en Engeland een overeenkomst aangegaan, waarbij Nederland toestemming kreeg, arbeiders in Suriname te doen immigreeren uit het dichtbevolkte Britsch-Indie.

De werfagenten zijn toen aanstonds aan 't werk gegaan, voornamelijk in de Noordelijke helft van Britsch-Indië, om overal menschen te werven, die zich in de hoop op een betere toekomst voor emigratie zouden laten vinden. Het schijnt dat deze agenten niet altijd even kieskeurig waren bij het aanwenden van de middelen om hun doel te bereiken. Ik heb persoonlijk een

1) Het is niet duidelijk, hoe dit, door Karstens genoemde, aantal in overeenstemming te brengen is met de mededeeling in het Koloniaal Verslag over 1862, die de niet-vrije bevolking van Suriname op 31 Dec. 1862 op 36484 stelt. 
oude Britsch-Indiër gekend, Ori geheeten, die mij graag vertelde, hoe hij uit zijn ouderlijk huis was weggelokt. Als jongen van 16 jaar was hij in de buurt van Benares, dat hij 't liefst met den ouden naam van Kāsi noemde, een paar armelijke koetjes van zijn ouders aan 't hoeden, toen hij met zulk een werfagent in aanraking kwam. Deze wees hem op de armoede van zijn vader, en schilderde hem Suriname af als een land van melk en honing. Bovendien stelde hij hem een hoog handgeld in 't verschiet, dat hij te Calcutta zou ontvangen. Ori bezweek voor de bekoring en, zonder naar het ouderlijk huis terug te keeren, liet hij zijn kudde in den steek en begaf zich te voet naar Benares, waar hij andere emigranten zou aantreffen. Alleen moest hij zeggen, dat hij niet 16 maar 18 jaar was, de leeftijdsgrens voor zelfstandige emigranten. Van Benares heeft hij den heelen langen afstand tot Calcutta weer te voet afgelegd. In Suriname is deze man Christen geworden en hij betreurde het steeds, dat hij zonder verlof en afscheid van zijn ouders was heengegaan. Voor zoover hij het kon, maakte hij zijn fout goed, door van zijn zuur verdiend geld een gedeelte naar zijn behoeftige ouders in Indië te zenden. In later jaren leefde hij afgezonderd van zijn stamgenooten in een klein hutje op de missiestatie Tamarin aan de Cottica als een Christen-asceet, toch nog echt Indisch, alleen met zijn koe, waardoor hij de Zusters en de kinderen van het internaat aldaar van melk kon voorzien. Bovenal echter was hij dankbaar, dat Gods Voorzienigheid zijn dwaalweg gebruikt had, om hem tot het Christendom te brengen.

Op 4 Juni 1873, enkele weken voordat het toezicht op de vrijgelaten slaven werd opgeheven, kwam het eerste schip met BritschIndische emigranten in Suriname aan. Het was een zeilschip, dat de bevallige naam droeg van Lāla Rookh, d.i. Tulpenwangige.

In den loop der jaren hebben 84 transportschepen ruim 34000 Britsch-Indiërs als contractanten aangevoerd, terwijl er bovendien vrije Britsch-Indische emigranten in de kolonie zijn binnengekomen.

Hierbij kan opgemerkt worden, dat ook in de Engelsche koloniën zelf Britsch-Indiërs zijn ingevoerd, zooals op de Fidzjieilanden, in Zuid-Afrika, in Britsch-Guyana, en op sommige West-Indische eilanden. Zoo bestaat b.v. de bevolking van Trinidad, St. Lucia en Jamaica voor een groot deel uit BritschIndiërs.

Toen echter de nationalistische beweging in Indiē, die de werving van emigranten als een vernedering deed zien, sterker werd, 
heeft Engeland in 1916 de emigratie gestaakt en in 1918 het tractaat van 1872 daaromtrent opgezegd. De Britsch-Indiërs in Suriname zelf hebben die opzegging trachten te voorkomen, daar zij meenden, dat zij zich hechter met hun geboorteland zouden verbonden blijven gevoelen, wanneer nog steeds nieuwe landgenooten zich bij hen zouden voegen.

Daar de Nederlandsche regeering al van te voren met een mogelijke beëindiging der immigratie uit Britsch-Indië rekening had gehouden, is men in 1890 begonnen ook arbeiders uit Java aan te voeren, waarmee men steeds is voortgegaan.

De Britsch-Indiërs in Suriname zijn voor verreweg het grootste deel afkomstig uit het eigenlijk Hindoestan, de Gangesvlakte, waar het Arische element veel duidelijker aan den dag treedt dan in het Zuiden, waar het Dravidisch element overheerscht. Zij behooren tot de meest verschillende kasten, ofschoon uit den aard der zaak de lagere kasten het sterkst vertegenwoordigd zijn.

Zij worden in Suriname door de andere bevolkingsgroepen veelal Koelies genoemd, omdat zij als arbeiders voor de plantages zijn uitgekomen, en zoo hebben zij den in Ned.-Indië daarvoor gebruikelijken naam gekregen, die echter op hen als een soort volksnaam is toegepast. $Z$ ij zelf beschouwen dien naam tegenwoordig als een beleediging en noemen zich bij voorkeur Hindoestanilog: d.i. Hindoestanen.

Het lijkt me niet misplaatst hier even den oorsprong van het woord Indië en Hindoe na te gaan, daar toch ook de naam van ons Oost- en West-Indiē en zelfs van het tijdschrift waarin dit artikel verschijnt - De West-Indische Gids - er mee gemoeid is! De beteekenis van ,Indië” is ,,rivierland”, afgeleid van Indus = Sindhu = rivier, zooals Rijnland is gevormd van Rijn, dat eigenlijk ook ,,rivier" beteekent ${ }^{1}$ ). Toen n.m. ongeveer 2000 jaar vóór Christus een gedeelte der Arische stammen zich van hun stamgenooten op de Iraansche hoogvlakte afscheidden, trokken deze door de Oxus-, Kaiber- en Bolanpassen en vestigden zich in het gebied van een groote rivier. Nu beteekent rivier in het oude Indo Arisch (en in 't latere Sanscrit) sindhu. Vandaar noemden de daar immigreerende Ariërs die rivier, die voor hen de rivier bij uitstek was, de Sindhu, zooals zij nog heet in 't Sanscrit, een naam, die ook overgebleven is voor een landstreek aan den benedenloop dier rivier: de landstreek Sindh.

De stamverwante Ariërs, die in het tegenwoordige Iran (dat

1) Zie Max Müller, Lectures on the Science of Language, 9th edition I blz. $264-265$ en 431 . 
afgeleid is van Ariër) waren achtergebleven, spraken echter de begin ,," als ",h" uit (zooals uit vele voorbeelden blijkt, b.v. soma-haoma) ${ }^{1}$ ). Zij noemden dus die rivier de Hindhu en de stammen, die zich aan haar oevers gevestigd hadden, de Hindoe's of rivierbewoners.

De Grieken, die met die streken kennis maakten, lieten de aspiratie, de ,h", weg en noemden de rivier: de Indus, en de omwoners: de Indoi. Van de Iraansche uitspraak van het Sanscritische woord sindhu $=$ rivier is dus de naam Hindoe en Hindoestan en Hindoestanen voortgekomen: $($ stan $=$ sthān $=$ verblijfplaats). Van den Iraanschen vorm is via den Griekschen de naam India en Indiërs afgeleid.

Eerst sedert de Mohamedaansche overheersching van de Moghul-keizers, toen zij zich tegenover andere volken pas goed van hun eigen aard rekenschap gaven, zijn de Indiërs zelf de benaming Hindoe en de daarvan afgeleide vormen gaan gebruiken. In de Veda's noemen zij zich steeds Aryas (Ariërs) en hun land Aryāvarta (toen het land tusschen Himālaya en Vindhyabergen). In de latere Sanscrit-litteratuur heeten de Indiërs Bhāratas d.i. de afstammelingen van Bharata, ${ }^{2}$ ) en het land Bhārata ${ }^{3}$ ) of Bhāratavarsha, d.i. het land der Bhāratas.

In het tegenwoordig spraakgebruik duidt: Hindoestanen den landsnaam der bewoners aan; Hindoe's een bepaalde godsdienstige overtuiging; Hindi, de taal van een gedeelte der Hindoestanen.

Ofschoon vele Britsch-Indiërs naar hun land zijn teruggekeerd na afloop van hun contracttijd of nog later, is hun getal in Suriname door geboorte aangegroeid tot \pm 45000 . De huwelijken zijn onder hen zeer vruchtbaar en hun toename zou daarom nog grooter zijn, wanneer er niet zooveel babys stierven door slechte

1) Vergelijk voor de wisseling van s en h in verwante Arische talen het Grieksche $\dot{\varepsilon} \sim \omega \omega=$ kruipen met het Latijnsche serpens, slang; sanscrit $=$ sarpa.

2) Bharata, de zoon van Sakuntala, was een legendarische stamvader der Indiërs. Tusschen twee families van zijn nakomelingen, de Kauravas en de Pāndavas, werd de groote oorlog gevoerd, waarvan het epos de Mahā-bhārata verhaalt. Mahā-bhārata is een afkorting van Mahā-bhārata-ākhyāna, d.i. het groote verhaal over de afstammelingen van Bharata.

s) Ook thans nog gebruiken de $\mathrm{Br}$. Indiërs graag dezen naam voor Indië, maar dan met een nieuwe gevoelswaarde van meer ideëele en cultureele beteekenis. Zoo heet b.v. de voornaamste vereeniging der Br.-Indiērs in Suriname Bhārat Oeday, de opkomst van Bhārat (Indië). 
verzorging en wegens de kinderhuwelijken, die vaak zwakke moeders opleveren. Want ook dit gebruik komt nog veel voor. Wel worden huwelijken van kinderen tusschen 6 en 10 jaar zeldzaam, maar regel is nog, dat meisjes op 11 à 13 jarigen leeftijd trouwen.

Ik had een groote lagere school in de rijstpolders van Nickerie, waar $600 \mathrm{Br}$.-Indische en 200 Javaansche kinderen onder leiding van de Soeurs Franciscanessen van Roosendaal onderricht ontvangen. Maar wanneer ik in de hoogere klassen enkele dagen achtereen een open plaats zag aan den meisjeskant en ik vroeg: „waar is Isardee?" of Soendari of Phoelbasi of hoe ze heette, dan kon ik er op rekenen, dat het antwoord was: zij ,moet” trouwen. Een heele enkeling van de meisjes haalde de 6de klas vóór dien tijd.

Ik zeg met opzet „moet” trouwen, want van vrije keuze is geen sprake; alles wordt door de ouders in elkaar gezet, zonder den jongen, en zeker het meisje niet, er in te hooren. Menigmaal heeft het meisje, den jongen bijna nooit gezien en van te voren nooit gesproken. Op den trouwdag moet het dan maar een soort liefde worden op 't eerste gezicht! Ik denk, dat onze Hollandsche jongelui op dit punt niet zoo handelbaar zouden zijn!

II. Hun economische beteekenis.

Hebben de Britsch-Indiërs in Suriname nu beantwoord aan de verwachtingen, die men van hen had? Over het geheel genomen, kan men bevestigend antwoorden.

Karsten vat in zijn reeds genoemd werk zijn oordeel aldus samen : „,De Britsch-Indiërs vormen op den duur in Suriname een bevolking, toegerust met de eigenschappen, welke een land vooruitbrengen” (blz. 5). ,Uit economisch oogpunt zijn deze immigranten een zegen geworden voor de Kolonie" (blz. 6). Zooals we reeds vermeld hebben, waren zij op de eerste plaats bestemd om den arbeid der vrijgelaten slaven bij den z.g. grooten landbouw op de plantages te vervangen, en daarin hebben zij zich geschikte werkkrachten betoond. Wel is het waar, dat hun immigratie het verdere verval der plantages niet heeft kunnen tegenhouden, maar dat lag niet hoofdzakelijk aan de qualiteit der werkkrachten, doch aan andere, van hen onafhankelijke, factoren, zooals het uitbreken van ziekten onder de gewassen en de steeds toenemende concurrentie van andere landen, zooals Birma, Java, Brazilië, Cuba, die gunstiger zijn gelegen, op de wereldmarkt.

Terwijl nu de groote cultures, van suiker, koffie, cacao, op 
weinige ondernemingen na, bijna verdwenen zijn, opent zich voor Suriname toch het vooruitzicht op een betere toekomst door een steeds toenemende ontwikkeling van den kleinen landbouw, als producent van rijst, citrusvruchten en bacoven - en door het opkomen van een economisch sterkeren middenstand. En van deze ontwikkeling komt een niet gering deel op rekening der $\mathrm{Br}$.Indiërs. Ofschoon men de Oostersche volken, als meer statisch, graag stelt tegenover de Westersche, als meer dynamisch, moet men van de Br.-Indiërs in Suriname zeggen, dat zij zeer actief en werkzaam zijn. Daarbij zijn zij uiterst spaarzaam.

De meesten van hen hebben zich na hun contracttijd in den kleinen landbouw gevestigd en vinden hun bestaan in rijstbouw, groenten- en veeteelt. Zij zijn het, die Paramaribo tegenwoordig zeer goedkoop van melk en groenten voorzien.

Maar de hoofdzaak blijft de rijstbouw. In den wereldoorlog van 1914-18 eerst is men in Suriname op groote schaal met de rijstcultuur begonnen. Sindsdien is rijst ook het hoofdvoedsel geworden van de inlandsche bevolking. En terwijl de veel kleinere hoeveelheid, die vóór dien tijd voor de consumptie in Suriname noodig was, nog gedeeltelijk moest ingevoerd worden, bestaat er de laatste decennia, bij een veel grooter inlandsch gebruik, reeds een aanzienlijk uitvoeroverschot, dat nog ieder jaar grooter wordt en vooral naar de Fransche West-Indische eilanden wordt verscheept.

Die groei van de rijstcultuur heeft den laatsten tijd een waren honger naar land doen ontstaan onder de Br.-Indiërs, en het is een verblijdend feit, dat het gouvernement, met name de gouverneur Kielstra en de districtscommissarissen De Rooy en Van Assenderp, allerwege door het aanleggen van nieuwe polders dien honger hebben trachten te stillen. Gelukkig, dat Suriname nog een onuitputtelijke reserve aan domeingrond bezit!

Doch niet alleen wil men tegenwoordig de quantiteit van den rijstoogst verhoogen, maar ook de qualiteit, zoodat het product een gezocht artikel kan worden op de buitenlandsche markt en de rijstbouw, die tot nog toe al te veel een pauperscultuur was, tot een middenstandsbedrijf kan opgeheven worden.

Bijzondere verdiensten hiervoor heeft het rijstbedrijf van den heer Van Dijk en zijn zonen te Nickerie, dat met steun van de Ned. regeering is gesticht. Met een weergalooze werkkracht, die ik jaren lang van nabij heb bewonderd, en een onverwoestbaar optimisme, hebben zij hun talenten gesteld in dienst van den kleinen landbouw, en zij hebben zich als Europeanen niet ontzien zelf mede den zwaarsten veldarbeid te verrichten. 
Een ander gedeelte der Br.-Indiërs heeft een levensonderhoud gevonden in verschillende ambachten, zooals kleermaker, goudsmid, autoverhuurder, of in den handel.

Ook daarin hebben zij succes gehad. Langzamerhand verschijnen er hoe langer hoe meer winkels van Br.-Indiërs in Suriname. Hiervoor hebben zij meer capaciteiten dan de zwarte en gekleurde Creoolsche bevolking, die zij over het hoofd groeien.

De Surinamers van Afrikaansche bloedmenging zijn wel geschikt voor de intellectueele beroepen - men vindt heel wat ambtenaren, medici, practizijns en onderwijzers onder hen maar omdat zij minder goed geld kunnen beheeren, houden ondernemingen, waarvoor bedrijtskapitaal noodig is, bij hen geen stand. De Br.-Indiërs daarentegen zijn in geldzaken uiterst bedachtzaam en bekwaam, en zoo komt het, dat er onder hen steeds meer kapitaalkrachtigen voorkomen. Dit manifesteert zich heel duidelijk bij publieke of onderhandsche verkoopingen van huizen of bedrijven, waarbij Br.-Indiërs steeds tot de gegadigden behooren. Reeds een aanmerkelijk gedeelte van de vaste eigendommen, groote huizen en winkels, te Paramaribo zijn in hun bezit. Gewoonlijk gaan zij zelf niet in die groote perceelen wonen, maar verhuren ze en blijven zich zelf met hun primitiever woningen tevreden stellen. Ten slotte toonen de $\mathrm{Br}$.-Indiërs geen mindere bekwaamheid voor de meer intellectueele beroepen. Reeds betrekkelijk velen hebben zich opgewerkt tot onderwijzer, catechist, ambtenaar, ja er zijn ook al enkele geneesheeren en advocaten onder hen.

Een schaduwzijde van de economische opkomst der Br.-Indiërs is, dat zij op verschillend gebied een uiterst zware concurrentie aan andere bevolkingsgroepen hebben aangedaan; zoo b.v. hebben hun melk en groentenleveranties de welvaart van de kleine kolonie der Hollandsche boeren, die zich omstreeks het midden der vorige eeuw nabij Paramaribo gevestigd hebben, aanmerkelijk doen dalen. Ook zijn door hun mededinging sommige handwerken voor de minder kapitaalkrachtige en meer behoeften hebbende Creoolsche bevolkingsgroep tot niet meer loonende geworden, b.v. het kleermakersambacht. Maar, alles bij elkaar genomen, kan men toch het woord van Karsten onderschrijven, als hij zegt, ,,dat Suriname zich gelukkig mag rekenen, dat het deze arbeidzame menschen onder zijn bewoners telt" (ibid. p. 6).

III. Hun verhouding tot de andere bevolkingsgroepen.

We kunnen hier de vraag stellen, of de bevolking van Suriname 
zelf ook zoo enthousiast is over de bevolkingsaanwinst in kwestie; m.a.w. hoe is de verhouding van de Br.-Indiërs tot de andere bevolkingsgroepen in de kolonie?

Hier komen vooral ter sprake de zwarte en gekleurde Creoolsche bevolking en de Europeanen.

Met de Boschnegers en de Indianen, die in de binnenlanden wonen, komen de Britsch-Indiërs weinig in aanraking, daar zij in de kuststreken zijn gevestigd.

Ook met de Javanen onderhouden zij geen nauwe betrekkingen, ofschoon zij vaak dezelfde polders bebouwen; maar ieder bepaalt zich tot zijn eigen gedeelte en woont met zijn landgenooten bijeen; elk der beide volken gaat zonder vijandschap en zonder vriendschap zijns weegs. Daarbij komt, dat de Javanen zich in de samenleving in Suriname geheel op den achtergrond houden.

Wat betreft hun verhouding tot de Creoolsche bevolking is de toestand wat ingewikkelder. De Creolen en de Br.-Indiërs zijn in de Surinaamsche inlandsche samenleving de twee drijvende krachten; vandaar, dat zij veel met elkaar in contact komen. In het algemeen kan men wel zeggen, dat de verhouding goed is, in zooverre dat er geen botsingen voorkomen, zooals men dat wel hoort van andere streken met gemengde bevolking (b.v. V.S. en Z.-Afrika). Maar toch blijkt bij nader kennismaking, dat de verhouding niet hartelijk is, ja eer stroef, met een zekere wederzijdsche afkeerigheid.

Wat zijn hiervan de oorzaken?

Vooreerst een algemeene, het groote taalverschil, om van de godsdienstige klove nu nog niet eens te spreken. De Br.-Indiërs hebben in Suriname, in tegenstelling met hun landgenooten in de Engelsche koloniën van West-Indië, sterk vastgehouden aan hun eigen taal: het Hindi. Afgezien van de ontwikkelden onder hen, die goed Nederlandsch spreken, gebruiken zij in het dagelijksche verkeer met de overige bevolking een gebrekkig Neger-Engelsch, maar dat blijft meer een markt- en winkeltaaltje. De taal, waarin zij zich kunnen uitspreken, is en blijft nog het Hindi.

St. Augustinus geeft ergens in een kernachtige spreuk een zeer rake psychologische karakteristiek van een situatie, zooals hierdoor tusschen Br.-Indiërs en Creolen ontstaat: ,Alienitas linguae alienat hominem ab homine, ita ut libentius ei sit cum cane suo, quam cum homine alieno", ,,verschil van taal vervreemdt den eenen mensch van den ander, zoodat hij zich beter op zijn gemak gevoelt met zijn eigen hond, dan met een mensch, die een vreemde 
taal spreekt". Dan zijn er verder bijzondere oorzaken voor de latente spanning in de verhouding aan te geven.

Van den kant der Creoolsche bevolking:

1e. De naijver der Creoolsche bevolking. De Creolen zien met leede oogen aan, dat de Br.-Indiërs hen economisch overvleugelen. Daarbij komt, dat de Creolen van de immigratie van de Javanen, die alles wat zij verdienen onmiddellijk weer uitgeven, hebben geprofiteerd, terwijl zij aan de Br.-Indiërs, die in hun behoeften door eigen winkels voorzien, weinig verdienen.

2e. Een zekere psychologische oorzaak. Vele Creolen, die van Neger-afkomst zijn, hebben een soort minderwaardigheidscomplex: door hun kleur en haar meenen zij bij andere rassen uiterlijk ten achter te staan. Tegenover Europeanen, die de leidende functies in de kolonie innemen, leggen zij zich daarbij neer. Maar tegenover een volk van een ander ras, dat de door hen benijde raseigenschappen ook vertoont, maar als vervangers van den slavenstand naar Suriname is gekomen, komt dat gevoel onbewust tot een reactie, en die reactie toont zich door zich boven die z.g. ingevoerde ,,koelies" te willen verheffen.

Van den kant der $\mathrm{Br}$-Indiërs zelf zijn er eveneens oorzaken, waardoor zij niet populair zijn. Bij Europeanen, die nooit met Br.-Indiërs in aanraking zijn geweest, en enkel hun kennis hebben opgedaan uit boeken over het ,Indische wonderland", uit redevoeringen van Gandhi of uit de poëzie van dichters als Tagore, is de sympathie, ja zelfs geestdrift, voor hen overwegend. Heel dikwijls is dat enthousiasme toe te schrijven aan een zekeren hang naar het exotische, somtijds ook aan modezucht of interessantdoenerij. Doch ook bij meer bezadigde naturen, bij wie men zulke drijfveeren niet mag veronderstellen, heerscht vaak het gebrek, dat zij alle Br.-Indiërs beoordeelen naar een geestelijke élite onder hen.

Europeanen, die zelf in Br.-Indië hebben gewoond, vallen soms in een ander uiterste, met name Engelsche ambtenaren, die alle $\mathrm{Br}$.-Indiërs verachtend als ,,natives” samenvatten. Zij kunnen geen goed meer in hen zien; voor hen geldt Indië als ,,the country of regret", het land van spijt, van ontgoocheling.

De waarheid ligt, dunkt me, ook hier in 't midden.

De $B r$.-Indiër in het algemeen heeft vele goede eigenschappen, zooals wij er boven reeds verschillende hebben vermeld. Daar zou men nog bij kunnen voegen zijn liefde voor ouders en kinderen, zijn gastvrijheid en aangeboren wellevendheid en, speciaal wat de vrouwen betreft, haar groote gereserveerdheid en zedig- 
heid in 't openbaar en haar bewonderenswaardige toewijding aan haar huisgezin, waarin zij zonder eenige ontspanning of afleiding geheel en al opgaan, van den tijd, dat zij kind-vrouwtje zijn af, tot haar hoogen ouderdom toe ${ }^{1}$ ).

Maar ook bezit de $\mathrm{Br}$.-Indiër verschillende minder goede hoedanigheden, die vooral in den omgang met andere rassen sterk op den voorgrond treden.

1e. Vooreerst kenmerken de Br.-Indiërs in Suriname zich door een gebrek aan socialen zin. Dat lijkt wel vreemd bij menschen, die juist uit het land van het kastensysteem afkomstig zijn, maar misschien is het kastensysteem er wel de schuld van. In bepaalde gebruiken, door de traditie gesanctionneerd, heerscht bij hen een ware kuddegeest, zoodat zij uit menschenvrees daarvan niet durven afwijken, b.v. groote feesten geven bij huwelijken, ook al ruineert hen dat. Maar in zaken, waar de traditie hen vrijlaat, zijn ze dan ook besliste individualisten, met wie het moeilijk is samen te zitten in vereenigingen van socialen, economischen, of welken aard ook.

2e. Een tweede eigenschap der Br.-Indiërs, die de hartelijke verhouding met de Creolen in den weg staat, is hun aangeboren hooghartigheid en een zekere raswaan, waartoe een overigens rechtmatige trots op een rijk cultuurbezit zich bij hen heeft ontwikkeld. Bij hen bespeurt men dezelfde neiging, als we reeds in de oude Veda's vinden, die n.m. om de tegenstelling tusschen de „Ariërs” en de z.g. „zwarte huid” (waarmee in de Veda's de Dravidas worden aangeduid) te accentueeren. Ofschoon vele Surinaamsche Br.-Indiërs al heel weinig Arisch bloed bezitten, zien zij toch met geringschatting neer op de zwarte Creolen en zij noemen hen „Kāferi", een woord dat aan het Arabisch is ontleend en in 't algemeen ,ongeloovige" en dan verder "Neger" beduidt.

Het gevolg van de onderlinge verhouding tusschen Br.-Indiërs en Creolen is, dat huwelijken tusschen hen zeldzaam zijn, (wat op zichzelf geen nadeel is), en zij niet aan elkanders familiefeesten

1) Een gezaghebbend man als Dubois mag terecht schrijven:

Whatever may be said to the contrary, Hindu women are naturally chaste. I would even go so far as to say that Hindu women are more virtuous than the women of many other more civilised countries. Their temperament is outwardly calm and equable, and though a passionate fire may smoulder underneath, without the igniting spark it will remain quiescent. Dubois - Beauchamp: „Hindu Manners, Customs and Ceremonies", bladz. 313-314. 
deelnemen. Waar zij door elkaar wonen, leven zij wel naast, maar niet met elkaar.

Voor ons Europeanen in Suriname hebben zij hoogachting, maar zij blijven op een afstand. $Z_{i j}$ hebben graag, dat men hun zegt, dat zij oorspronkelijk van hetzelfde ras zijn als wij. En juist omdat zij bij de inlandsche bevolking niet bemind zijn en zich van die impopulariteit ook bewust zijn, toonen zij een groote aanhankelijkheid voor ons, wanneer wij hun onze sympathie geven. Zoo werd b.v. mijn voorganger bij het werk onder de Britsch-Indiërs, Pater Franssen, door hen op de handen gedragen. Wanneer ik soms bij hen koel ontvangen werd, dan vroeg ik maar: tum Pater Frans jante ho? Kent U Pater Frans? En dan was het ijs spoedig gebroken.

Ik herinner me, dat ik eens aan een oud verschrompeld Hindoevrouwtje, dat zich al heel weinig toeschietelijk toonde, die vraag stelde. Aanstonds begonnen die doffe oogen te schitteren: ,ji hān sahib, Pater Frans Hindustanilog chahé hé! Ja, Sahib, Pater Franssen heeft de Hindoestanen lief!

Wederliefde is hier, zooals altijd, ook het loon van liefde!

\section{Hun verhouding tot het gouvernement.}

Van den kant van het gouvernement hebben de Br.-Indiërs, vooral in de eerste decennia der immigratie, een bijzondere bescherming genoten. Een speciale hooge ambtenaar was tot voor enkele jaren uitsluitend met de zorg voor hun aangelegenheden belast, n.l. de agent-generaal voor de Immigratie, als hoedanig een Cateau van Roseveldt en een Van Drimmelen, Koelipapa bijgenaamd, een groote populariteit onder hen verworven hebben. Thans is aan den gouvernements-secretaris de zorg voor hun belangen opgedragen.

Het gevolg was, dat de Br.-Indiërs na hun contracttijd in Suriname bleven en zich aan hun nieuwe vaderland hebben gehecht. Zij zijn zeer Nederlandsch gezind geworden, en zij leven mee met het wel en wee van Groot-Nederland. Op nationale feestdagen doen zij voor niemand onder in betuigingen van trouw en aanhankelijkheid aan het Bestuur. Een ander gevolg hiervan is geweest, dat zij een beetje verwend zijn. Voor het districtsbestuur zijn ze soms lastige luitjes. Met alle mogelijke questies komen zij naar den districtscommissaris ter oplossing en beslechting.

Een bekend redacteur der N.R. Courant heeft eens zoo'n audiëntie-morgen bijgewoond op 't districtskantoor van de Combé, en hij verklaarde toen later in zijn reisverhaal, dat een dis- 
trictscommissaris werkelijk een Salomo's wijsheid moet bezitten, om al die klagende menschen tevreden naar huis te kunnen sturen.

Het gouvernement heeft er ook naar gestreefd de koloniale wetgeving aan hun nationale en godsdienstige gebruiken aan te passen. Zoo werd vroeger op die gouvernementsscholen, welke door $\mathrm{Br}$.-Indische kinderen werden bezocht, ook les gegeven in hun eigen taal: het Hindi voor de Hindoes, en het Urdu voor de Mohamedanen onder hen. Doch dit is later afgeschaft; thans wordt uitsluitend in 't Nederlandsch onderwijs gegeven. Alleen op de scholen van de Missie en de Zending worden buiten de officieele lesuren eenige lessen in de eigen taal gegeven.

Dan werd de leeftijdsgrens voor het huwelijk van meisjes verlaagd tot 13 jaar.

In de verdere herziening van de huwelijkswetgeving ten opzichte der Br.-Indiërs is het Bestuur niet gelukkig geweest. Vele Br.-Indiërs sluiten n.l. hun huwelijk alleen voor hun eigen priesters (panditen geheeten bij de Hindoes, en Maulwis ${ }^{1}$ ) bij de Mahomedanen) en niet tevens voor den burgerlijken stand. Zulk een huwelijk wordt natuurlijk dan niet door het gouvernement erkend; maar het is ook niet verboden, zooals wel ten opzichte van de christelijke gezindten. Juist echter omdat die huwelijken geen rechtskracht bezitten en toch veelvuldig voorkomen, verkeert de $\mathrm{Br}$.-Indische vrouw in een zeer ongunstige positie. In de meeste gevallen van verlating, scheiding en derg. heeft zij geen gehoor bij de rechterlijke macht. Met de loffelijke bedoeling deze positie te verbeteren en de wettelijke huwelijken te bevorderen, heeft het Bestuur nu een concept van huwelijkswetgeving ontworpen, waarin het $\mathrm{Br}$.-Indische huwelijk, dat voor de priesters wordt gesloten, ook vanzelf rechtskracht krijgt. Het Gouvernement ging uit van de veronderstelling, dat de Br.-Indiërs van het burgerlijk huwelijk werden afgeschrikt uit godsdienstige motieven. Het merkwaardige echter is, dat, toen dit ontwerp, niet lang voor den oorlog, in de Koloniale Staten kwam, het niet alleen werd verworpen door de vertegenwoordigers der andere bevolkingsgroepen, die er een onbillijkheid in zagen tegenover de christelijke gezindten, maar ook door de drie Br.-Indiërs, die zitting hebben in de Staten. Zij willen liever niet onder een uitzonderingswet leven, daar zij dat een vernedering vinden. Dat zij tot nu toe weinig gebruik maken van het burgerlijk huwelijk, komt hoofdzakelijk hieruit voort, dat het hun toch geoorloofd is,

1) Eigenlijk geen priesters, maar voorgangers, daar de Islām geen priesterschap kent. 
godsdienstig te trouwen zonder voorafgaand burgerlijk huwelijk, en vooral, omdat het sluiten van een burgerlijk huwelijk hen in aanraking brengt, met den Surinaamschen Burgerlijken Stand, hetgeen voor hen gewoonlijk niet verkwikkelijk is.

De heele bureaucratische machine n.l., die in een normaal ontwikkeld Europeesch land haar nut kan hebben, wordt ook in werking gebracht tegenover de immigranten. Daar er echter bij het opmaken van geboorte- en overlijdensakten in hun vreemde namen zoo gemakkelijk fouten insluipen, komen er de president van het Hof van Justitie, de procureur-generaal, advocaten, rechters, beëedigde getuigen en wie al niet meer bij te pas, om die weer in orde te maken. En daar deze heeren ook niet allen pro Deo werken, komen er op de meeste burgerlijke huwelijken van Br.-Indiërs extra-hooge kosten.

Om slechts even te illustreeren, hoe gemakkelijk officieële acten, waarin $\mathrm{Br}$.-Indische namen voorkomen, foutief kunnen zijn, behoef ik er maar aan te herinneren, dat de volwassen Br.Indiër gewoonlijk een anderen naam draagt, dan hij bij zijn geboorte heeft gekregen (oorzaak van onzekerheid aangaande de persoon) en vervolgens, dat er geen vaste methode bestaat voor het spellen van $\mathrm{Br}$.-Indische namen.

Er worden n.l. afwisselend drie verschillende methoden gevolgd: de Br.-Indische, de Engelsche of de Hollandsche. Een naam b.v. als Siuraji krijgt een heel ander uiterlijk, naar gelang hij op zijn Indisch, Engelsch of Hollandsch wordt gespeld en geschreven. En zoo komt men van de eene verbastering tot de andere. Voor insiders is het werkelijk vermakelijk in de rubriek „,Burgerlijke Stand” in Surinaamsche kranten na te gaan, hoe daar de mooie, zinrijke Br.-Indische namen tot allerlei puzzles worden verhaspeld.

Daarbij komt nog, dat de meeste oudere Br.-Indiërs de officieele akten, die alle in het Nederlandsch zijn gesteld, niet kunnen lezen en daarom op den duur niet meer weten, welke papieren zij moeten bewaren, welke niet. Het is mij al menigmaal overkomen, dat, wanneer ik om het geboortebewijs van een kind vroeg, zij mij een quitantie van de gasfabriek, een dwangbevel van de belasting, of een deurwaarders-exploit of iets dergelijks overreikten! Sommigen zijn zoo verstandig om alle mogelijke papieren, die binnen komen, in een kistje te bewaren, waarin je dan zelf maar moet uitzoeken. Ik maak dan gewoonlijk van de gelegenheid gebruik al het waardelooze op te ruimen.

Een vereenvoudiging derhalve van de formaliteiten voor den 
Burgerlijken Stand zou ongetwijfeld de frequentie van het burgerlijk huwelijk onder de $\mathrm{Br}$.-Indiërs verhoogen en tevens een uitzonderingswetgeving op dit gebied overbodig maken.

Hier raken we aan een teer punt in de koloniale politiek, n.l. de moeilijkheid, om van zulke heterogeene elementen, als waaruit de Surinaamsche bevolking bestaat, een min of meer homogeen geheel te maken.

De imperialist onder de Engelsche dichters: Rudyard Kipling heeft in zijn Ballade van Oost en West ${ }^{1}$ ), het bekende vers de wereld ingezonden:

Oh, East is East, and West is West, and never the twain shall meet,

waarop de minder bekende regel volgt:

Till Earth and Sky stand presently at God's great Judgment Seat. Men hoort ' $t$ : Kipling is niet erg optimistisch aangaande het tijdstip, waarop Oost en West elkaar zullen ontmoeten; hij verwacht het niet dichter bij, dan het einde der tijden, at God's Judgment Seat!

Toch schijnt het me, dat we speciaal voor Suriname, waar zoo verschillende rassen reeds in een staatkundige eenheid van een Nederl. gebiedsdeel te zamen zijn gebracht, niet zoo pessimistisch behoeven te zijn.

En dan denk ik hier als punt van ontmoeting op de eerste plaats aan het Christendom, dat in zich de kracht heeft, de meest verschillende rassen in een hoogere geestelijke eenheid van gelooven, denken en voelen te vereenigen.

Gelijk het Christendom in de 1ste eeuw de scheidsmuur tusschen Joden en Heidenen heeft neergehaald, zooals onder Clovis in de 6de eeuw het aannemen van het Christendom de snelle assimilatie van velerlei Europeesche stammen, tot een sterk homogeen Frankisch rijk heeft bewerkt, zoo zou ook in Suriname (als we het kleine met het groote mogen vergelijken) het Christendom tusschen de verschillende bevolkingsgroepen een eenheid in de hoogste levenssfeer tot stand kunnen brengen. En daarom zou ik ook bescheidenlijk de vraag durven stellen, of zelfs van het louter menschelijk standpunt van koloniaal beleid bezien, de uitbreiding van het Christendom onder de niet-christelijke bevolkingsgroepen in Suriname niet een intensievere belangstelling van het bestuur mocht hebben, dan tot nu toe het geval is?

En zoo zijn we van zelf bij ons laatste punt aanbeland.

1) In zijn boek „,Barrack Room Ballads”, blz. 75-83. 


\section{Hun verhouding tot het Christendom.}

Driekwart van de Surinaamsche Br.-Indiërs behoren van huis uit tot het Hindoeisme. Zij zijn dus Hindoes, terwijl $\frac{1}{4}$ gedeelte den Islam belijdt. De eersten spreken het Hindi, een nieuwIndische taal, die 't meest op 't Sanscrit gelijkt, met de Sanscritletter wordt geschreven en zich tot het Sanscrit verhoudt ongeveer als het Italiaansch tot het Latijn. De 2de categorie spreekt het $U r d u$ of Hindustāni ${ }^{1}$ ), dat een soort Hindi is, maar rijkelijk met Perzische en Arabische woorden doorspekt, met Arabische letters geschreven, en ontstaan in de legers van de Moghulkeizers, zooals Baber en Akbar; vandaar ook de naam Urdu = leger: een afkorting van Zabān-i- Urdu = d.i. taal van het leger ${ }^{2}$ ). Maar omdat de Hindoes in Suriname de overhand hebben, is hun taal, het Hindi, daar de algemeen gangbare geworden, ook onder de Mohamedanen.

Op het Hindoeisme in 't algemeen kan ik hier niet nader ingaan. Daarvoor zou een afzonderlijk artikel nog niet voldoende zijn.

Er is geen godsdienst, die zoo moeilijk te definieeren valt, juist omdat, zooals de groote Fransche Indoloog Auguste Barth zoo karakteristiek heeft gezegd: „La diversité en est l'essence même", De verscheidenheid, ja de tegenspraak is er het wezen zelf van ${ }^{3}$ ). Historisch zou men het heel vagelijk kunnen bepalen als de godsdienst van het overgroote meerendeel der tegenwoordige Indiërs, zooals die zich van 1000 j. vóór Christus uit de Veda's, de groote Epen en de Purānas ontwikkeld heeft, tot op onze dagen. Zoo goed als alle religieuse verschijningsvormen, animisme, polytheisme, atheïsme, theisme, pantheisme, en theopanisme, vinden in het Hindoeisme een eigen plaats. Gelijk Indië zelf is het een „Tummelplatz unvermittelter Gegensätze" 4).

Het Surinaamsche Hindoeisme zwenkt tusschen polytheisme en

$\left.{ }^{1}\right)$ Zie het interessante artikel van Prof. J. Ph. Vogel: ,De eerste grammatica van het Hindoestansch". Uitgegeven in ,Mededeelingen der Nederlandsche Academie van Wetenschappen, Afdeeling Letterkunde; Nieuwe reeks, deel 4, No. 15. Uitgave van de N.V. NoordHollandsche Uitgevers Maatschappij, Amsterdam 1941. Hieruit blijkt, dat de eerste grammatica van het Urdu is geschreven in 't Nederlandsch, door een ambtenaar van de Oost-Indisch Compagnie, Ketelaar genaamd, \pm 1700 .

2) Ons woord ,horde", legerbende is hetzelfde woord als urdu.

s) In de Engelsche vertaling van zijn werk onder den titel: ,,The religions of India"' op bladz. 153.

•) Zie Prof. R. Schmidt, „Das alte und moderne Indien”, bladz. 2. 
monotheisme. In de praktijk worden allerlei goden vereerd, vooral Vishnu en zijn incarnaties Rama en Krishna, dan Ganesha, de god met olifantskop, Hanumān, de apengod, en Siva. Maar mijn persoonlijke ervaring is, dat de Surinaamsche Hindoes in hun hart theoretisch één persoonlijken God aannemen. Als ik hun vaak vraag: Hoeveel goden zijn er nu eigenlijk? dan is hun antwoord bijna altijd: ekhi Parmeswar; één God, die zij dan noemen: Iswar (Heer) of Parmeswar (hoogste Heer) of Bhagwān (i.h. sanscrit bhagavat = gelukkig, heerlijk) of Mālik (van het Arabisch en Hebr. heer, bezitter, koning) of Paramātmā (hoogste Geest).

De meeste Surinaamsche Hindoes behooren tot een of anderen vorm van het orthodoxe Hindoeïsme, dat zij zelf de Sanatana Dharm; , ,de eeuwige godsdienst”, noemen.

In de laatste jaren hebben ook velen, vooral onder de meer ontwikkelden, zich aangesloten bij een in 1875 door Swami Dayananda Sarasvati in Indië gestichte sekte: de Arya Samāj (de Arische gemeente, een soort hervormd, rationalistisch Hindoeisme, dat zich van veel uitwassen van het orthodoxe wil ontdoen. Hun leuze is: Terug naar de Veda's! Alle latere heilige geschriften erkennen zij niet. In Br.-Indië zijn zij zeer nationalistisch; in Suriname, waar nationalisme voor hen geen beteekenis heeft, is het niet zoo zeer een godsdienstige secte geworden als wel een vereeniging van bewonderaars der Oud-Indische cultuur. Feitelijk hebben zij al heel weinig geloof. Een kenmerk van de Arya Samāj, zoowel in Br.-Indië als in Suriname, is, dat zij zeer agressief en anti-christelijk is, gelijk ook zijn stichter was. Den Surinaamsche Hindoes noemen het: ,,jhanjhat ka dharm”, ,,de godsdienst, die altijd ruzie zoekt".

De Mohamedanen onder de Sur. Br.-Indiërs behooren meestal tot den orthodoxen Islām, dus tot de Sunnieten en wel tot de richting der Hanafieten (naar den schriftgeleerde Aboe Hanifa) in tegenstelling met de Javanen, die de Sjafiitische richting volgen. Met hun fanatiek geloof aan Allah alleen, zien zij geringschattend neer op de Hindoes, die zij als onwetende afgodaanbidders beschouwen. Tusschen beide groepen $\mathrm{Br}$.-Indiërs komen somtijds wrijvingen en botsingen voor; zoo b.v. toen enkele jaren geleden de Mohamedanen in den Corantijnpolder te Nickerie het gewaagd hadden een koe, het heilige dier der Hindoes, te slachten. Sinsdien is het slachten van koeien op de vestigingsplaatsen der $\mathrm{Br}$.-Indiërs verboden.

Hoe staat het nu met de Evangelieprediking onder hen?

Het spreekt van zelf, dat de zendeling en de missionaris zich 
daarbij niet door utiliteitsmotieven laat leiden, zooals dat bij koloniale regeeringen kan gebeuren. Hun beginsel is de opdracht van Christus: ,Gaat heel de wereld door en predikt het Evangelie aan ieder schepsel" (Marcus. 16,15) en de leer, die opgesloten ligt in de oude Sanscritspreuk der Indiërs: ,satyān nāsti paro dharmah" d.i. ,Er is geen hooger plicht dan de waarheid”. Derhalve, indien de waarheid de hoogste plicht is voor den mensch, dan kan men zijn medemensch ook geen grooter dienst bewijzen, dan hem de waarheid te leeren. Waar nu de christelijke geloofsverkondiger overtuigd is, in het bezit te zijn van dat hoogste aller goederen, wil hij dien rijkdom ook aan anderen mededeelen.

Behalve de algemeene moeilijkheden zijn er bij het Hindoeisme twee bijzondere hinderpalen, die den overgang tot het Christendom in den weg staan.

le. De doordringing van heel het maatschappelijk en familieleven door den Hindoe-godsdienst. Verlaat iemand dus zijn Hindoe-geloof, dan verliest hij ook zijn plaats in de Br.-Indische samenleving, ofschoon dit in Suriname, waar ook het kastensysteem afslijt, niet meer zoo ten volle waar is.

2e. De ,all-comprehensiveness" van het Hindoeisme, d.i. het vermogen om allerlei leerstukken van andere religies op te nemen, zonder de kracht te bezitten daarmee tegenstrijdige elementen af te stooten. Daaruit ontstaat bij den Hindoe een heel eigenaardige geesteshouding. Wanneer wij een godsdienst aannemen, dan verwerpen wij de tegenovergestelde. Zoo is het niet bij den Hindoe; hij is vaak wel geneigd de leeringen van het Christendom te aanvaarden, maar terzelfder tijd wil hij vasthouden aan begrippen uit zijn vroeger geloof, die daarmee lijnrecht in strijd zijn.

Toch is het werk van zending en missie onder hen in Suriname niet zonder succes geweest.

In 1901 begon de Evangelische Broedergemeente onder de Br.Indiërs een geregelde zending, toen een speciaal voor hen gevormde leeraar, de Eerw. Heer Wenzel, in Suriname aankwam. Sindsdien is het werk gestadig toegenomen, zoodat thans op verscheidene plaatsen kleine gemeenten zijn gevormd.

De R.K. Missie is in 1904 systematisch met het bekeeringswerk begonnen, toen de Eerw. Pater Luykx zich geheel aan deze taak ging geven. Hij had in 't begin 't geluk een zeer kinderrijke Brahmanenfamilie voor 't Christendom te winnen. Verscheidene van deze kinderen werden in verloop van tijd invloedrijke medehelpers van de Missie, daar ook in Suriname de Brahmanen nog steeds een sterk geestelijk overwicht over hun andere landge- 
nooten hebben. In 1913 werd aan de Mahonylaan te Paramaribo een internaat gesticht met een afdeeling voor jongens en (in 1915) een voor meisjes, Rajpur genaamd: d.i. Koningenplaats, zoo genoemd naar de Koningen of Wijzen uit het Oosten, die als eerstelingen uit het heidendom het pasgeboren Christuskind hun hulde kwamen bieden. Daar worden door de Zusters van Liefde uit Tilburg kinderen van Br.-Indiërs, die daarvoor door hun ouders worden afgestaan, en ook wel weezen, opgevoed in den Christelijken godsdienst, maar met behoud van die eigen gebruiken, die met het Christendom zijn overeen te brengen.

Onder de populaire „Koeli-pater" Pater Franssen is deze inrichting tot grooten bloei gekomen. Al menig Katholiek Br.Indisch echtpaartje heeft deze stichting, waar de meisjes tot haar huwelijk blijven, opgeleverd, en de ondervinding heeft geleerd, dat deze bekeerlingen zich van hun landgenooten het best aanpassen aan de andere Surinaamsche bevolking, terwijl zij toch de goede eigenschappen en gebruiken van hun eigen ras niet hebben verloren.

Ook het Gouvernement heeft de beteekenis hiervan voor Suriname begrepen en daarom aan dit huis een welkome en dankbaar aanvaarde subsidie toegekend.

Op een 26 K.M. van Paramaribo, langs de spoorbaan, is ook een Kath. Br.-Indische landbouwkolonie gesticht, waar de getrouwde paren en de grootere jongens zich desgewenscht kunnen vestigen. Op het oogenblik werken 3 à 4 Paters uitsluitend onder de Br.-Indiërs. Het aantal Br.-Indiërs, die Kath. gedoopt zijn en tevens min of meer de Christelijke levenspraktijk hebben aangenomen, kan men op \pm 2000 schatten.

Verder bezoeken nog ruim 2000 niet gedoopte $\mathrm{Br}$.-Indische kinderen de scholen der Missie. In Nickerie alleen had ik er 700 onder mijn gehoor op de catechismus. Ook hiervan is de beteekenis voor Suriname niet te onderschatten. Want het is een feit, dat het Hindoeisme langzaam aan zijn vat op de jongeren in Suriname verliest. Maar wanneer zij nu op school geen principieele christelijke beginselen daarvoor in de plaats krijgen, groeit de opkomende jeugd gemakkelijk op tot stuurlooze menschen, zonder eenige vaste godsdienstige overtuiging, een mentaliteit, die voor een goed geordend staatsbestel en een bloeiend gemeenschapsleven zeker niet de gunstigste voedingsbodem biedt.

Tot slot nog een enkel woord over de nieuwe methode, die de laatste jaren bij de bekeering, speciaal der Hindoes, wordt toegepast. Deze nieuwe methode is van Protestantsche zijde in 
zwang gebracht door mannen als Sadhoe Soendar Singh. en den beroemden Amerikaanschen zendeling Stanley Jones; van Katholieke zijde door den Kath. Brahmaan Upadhyaya Bramabandhav en de Jezuiëten Wallace, Johanns en Dandoy. Deze methode gaat uit van Christus' woord ,Ik ben niet gekomen om af te breken, maar om te vervolmaken". (Matth. 5, 17).

Het Hindoeisme bergt ontegenzeggelijk in zich een schat van religieuse ideeën van de hoogste waarde, maar zij zijn overwoekerd, gelijk de kunst van hun tempels, door allerlei uitwassen.

De taak van den Christen-missionaris is het nu aan te toonen, dat de Hindoe, wanneer hij Christen wordt, niet ten volle breekt met zijn eigen religieus cultuurbezit, maar dat hij wat schoon en goed was in zijn eigen opvattingen, veredeld en verrijkt terugvindt in 't Christendom. "Christus alleen kan, de erfenis van Indië voor hen zelf en voor ons redden", heeft Stanley Jones ${ }^{1}$ ) zoo schoon gezegd.

Christus zal aldus de Consummator, de Voltooier, zijn van den Sanātana Dharma, den eeuwigen godsdienst der Indiërs! ${ }^{2}$ ) Om dit te helpen verwezelijken hoop ook ik, na een spoedige terugkeer naar Suriname, mijn zwakke krachten te mogen besteden, geinspireerd daarbij, niet door het woord van Kipling: „Oh East is East and West is West, and never the twain shall meet", maar door het woord van Paulus aan de Galaten, dat eens voor goed afrekent met alle onderscheid van ras, stand en sexe: ,Thans is er geen Jood meer of Heiden, geen slaaf en vrije, geen man en geen vrouw, want allen zijt gij één in Christus Jezus" (ad. Gal. 3,28 ).

Noordwijkerhout 21 Dec. 1941.

1) Vergelijk ook Stanley Jones ,Christus en de Tafelronde”, blz. 91.

2) Zie P. Johanns, S.J., ,"Vers le Christ par le Vedanta”, Leuven 1933. In dit verband wil ik er nog aan herinneren, dat bij de promotie van Pater P. J. Zoetmulder S. J. tot doctor in de Indonesische taal en letterkunde aan de Rijksuniversiteit te Leiden in 1935, zich onder de te verdedigen stellingen ook de volgende thesis bevond: „De Thomistische philosophie is vooral door haar leer over de creatio, een goede basis niet alleen voor de bestudeering, maar ook voor verderen uitbouw der Vedānta-philosophie. Daarom verdienen de studies van P. Johanns een ruimere verspreiding"'. 